\title{
EFFECTIVENESS OF TOMATO AS TRAP CROP FOR LIRIOMYZACHINENSISKATO (DIPTERA : AGROMYZIDAE)AND ITS PARASITOID ON RED ONION CROPS ( ALLIUM CEPAVARAGGREGATUM )
}

\author{
Ni Putu Sukarini ${ }^{1)}$, Shahabuddin ${ }^{2)}$ Hasriyanti ${ }^{2)}$ \\ ${ }^{1)}$ Agrotechnology Program, Faculty of Agriculture, University of Tadualko, Palu, E-mail : niputu602@gmail.com \\ ${ }^{2)}$ Faculty of Agriculture, University of Tadualko, Palu. E-mail : shahabsaleh@gmail.com \\ E-mail : hasrianty.amrana@gmail.com
}

\begin{abstract}
This research aimed to find out the effectiveness of tomatoes as a trap crop to control liriomyzachinencis, the leaf cutter pest $\mathrm{s}$ and its parasitoids on onion plants varieties with a different planting time at Palu valley.This research was conducted on June until August 2015 in Langaleso village, west Dolo of Sigibiromaru Regency, central Sulawesi procince. Also futher research was conducted at the laboratory of pest and plant disease of agriculture faculty, tadulako university palu. This research applied an experimental research design by using cluster random sampling. It was treated with one kind of trap crop (tomatoes) with four different planting time, namely : $0,2,4$, and 6 weeks before the onion being planted. The parameters observed was a kind of liriomyzachinensis, amount of excavation, and the abundance of parasitoid at the level of parasitism. The results of thi research showeded the average number of excavation liriomyzachinencis on the control plants on the eighth week was higher than average number of excavation liriomyzachinencis on the other plants which was given a trap crop treatment. There were two species of parasitoids found on the research area, namely Hemiptarsnusvaricornis and Opius sp. With a level of parasitism which range $23 \%$ until $27 \%$.
\end{abstract}

Keywords :Liriomymza chinencis, Trap Crop.

\section{INTRODUCTION}

Red onion varieties Palu Valley is one of the horticultural crops that have high economic value and become the main commodity of Central Sulawesi. Besides to be used as fried onion red onion can also be used as a spice by some people of Central Sulawesi. Local Palu red onion when viewed from the potential land and the potential for existing production, and supported by natural resources that enable increased production and quality results in order to better compete with the other regions because it has a unique and specific properties that remain savory, and the aroma does not change even in the store in a relatively long time (Saleh et al., 2009). Plant pest organisms (OPT) recently attacked the Palu Valley varieties of leaf varieties ie leafminer species Liriomyza chinensis Kato (Diptera: Agromyzidae) and reported that it have become a major pest of red meat because it can cause enormous losses to crop failure (BP4 SULTENG, 2006).

Shahabuddin et al. (2012), reported that the type of leafminer fly that attacked the cultivation area of shallot farmers in Central Sulawesi is L. chinencis. This pest has been present in the Valley of Palu since the 2000s, but it was reported in 2007. Initially, the area affected was only narrow, but the attacks grew from year to year, causing enormous losses for farmers because of their harvest failure (puso).

To control leafminer (L. chinensis), farmers use chemical insecticides 1 to 2 times a week. The increasing use of synthetic pesticides creates many problems. 
Increased pesticide residue poses a danger to non-target organisms such as humans and the environment and the emergence of resistant organisms against certain pesticides (Kabaru and Gichia, 2001).

Another alternative that can be done for control is the approach to the protection of plants that are environmentally sound and avoid the risks posed to humans and other organisms. Biological control by utilizing natural enemies is the right choice. The parasitoid Hemiptarsenus varicornis Grinault is a potential natural enemy to control Liriomyza sp. Ectoparasitoid by putting eggs in larvae (Agus, 2007).

Until now control of L. chinensis with the concept of IPM has been done, one of them by using a trap plant. There are several types of plants that potentially made in the plant trap .one of them by using tomato plants as a trap plant to control pests L. chinencis (Shahabuddin et al., 2013).

For that researchers took the initiative to use tomato plant as trap plant, because tomato plants have faster growth and development of onion plants and also good for the development of Liriomyza and parasitoidnya, so as to reduce losses in the main crop.

The objective of this research was to know the effectiveness of tomato plant as a trap plant for the controlling of leafminer of L. chinensis and its parasitoid on the red onion plant at different planting periods 0,2 , 4 , and 6 week before red onion planting.

\section{RESEARCH METHODS}

This research was conducted in Langaleso village, West Dolo sub-district, Sigi District, Central Sulawesi Province, and in Plant Disease Pest and Disease Laboratory, Faculty of Agriculture, University ofTadulako Palu. The research went on June to August 2015

The research used experimental method designed with Randomized Block Design with 1 plant trap type (tomato) with 4 different planting times ie $0,2,4$, and 6 weeks before the onion crop was planted.
Treatment was repeated 3 times and added 3 control plots to obtain 15 unit experiments.

Research Implementation. Before tomatoes planting as trap crops, then seedling the seeds of tomatoes first by planting the seeds on the planting holes made with a distance of $5 \mathrm{~cm}$ and the depth of the planting hole about $1 \mathrm{~cm}$. In one planting hole can be filled 1 or 2 seeds, then covered the ground thinly, after that done the maintenance of watering, weeding, fertilization, after age 35-45 days, tomato seedlings ready for the move and planted in the planting hole with a distance of $50 \times 60 \mathrm{~cm}$, and the distance of the tomato plant hole $15 \mathrm{~cm}$ from the edge of the plot (either from the right margin, left, front or back). Each plot had 20 plants so the total number of plants for 15 plots were 300 tomato plants. After a few weeks tomato plants in planting, made preparations for planting red onion as the main plant that was clearing the land first, then made a bed with an area of $3 \times 1$ meters and height of beds $25 \mathrm{~cm}$. Local red onion Palu planting with spacing $20 \times 15 \mathrm{~cm}$, watering plants, weeding and stacking.

Leaf sampling. Leaf sampling was done by taking the red onion leaves. The Lambah Palu was attacked by L. chinensis, each sub plot was taken 10 leaf blossom This leaves were collected every week, since the plants were 3 to $8 \mathrm{MST}$. With the symptoms of attack there were white spots due to puncture ovipositor, and zizgzag form of burrow bend. If there was a symptom of a slimming attack then the stricken leaves taken and inserted in a jar and then labeled. Plastic bags were labeled with information about the date of leaf sampling and plant life. Furthermore, the leaves were brought to the laboratory.

\section{Liriomyza chinencis dan Its Parasitoid.} Maintenance and observation of $L$. chinensis and its parasitoid refered to Rustam et al. (2008) and Susilawati (2004), with some modifications. The leaf samples collected from the field were cleansed from dirt by using aquiline, then put into a black 
jar plastic that had been painted black with diameter $9 \mathrm{~cm}$ and height $16 \mathrm{~cm}$. In the center of the container was mounted a wire bulkhead as a leaf support, on the top of the plastic jar holder and placed a small aqua bottle with the upside position $(5 \mathrm{~cm}$ diameter, height $16 \mathrm{~cm}$ ) to accommodate $\mathrm{L}$. chinensis imago and its emerging parasitoid imago, and labeled by time of onion planting. The number of L. chinensis and parasitoid imago appearing observed daily. Imago parasitoids were then fed into a micro tube containing $70 \%$ alcohol to be identified in the laboratory.

Liriomyza chinensis dan Parasitoid identification . Identification of the types of chiropods (Liriomiza chinensis) and parasitoid which had been done by refered to Shiao (2004), as well as online identification (Konishi, 1998 and Fisher et al., 2006). Identification of L. chinensis and parasitoid were also performed by comparing with key specimens already present in the laboratory. Identification of $L$. chinensis and its parasitoid was performed by microscope in stages according to the samples of plants taken from the field.

\section{Observation Variables}

The number of Liriomyza and L Chinensis bends. L. chinensis species was known from the observation and identification results, whereas the number of L. chinensis corals was calculated on 10 clumps / plots that were randomly assigned diagonally, and observed since 3 weeks after planting and repeated every 1 week, harvested at 8 weeks after planting.

Types and Abundance of Parasitoids. the types and abundance of parasitoids were known know from the identification results, and from the observation of red onion leaf which was infected by L. chinensis.

Parasitoid Parasitization Level. Calculation of parasitoid parasitization rate refered to Rustam et al. (2006), using the following formula:

$$
\begin{aligned}
& \text { Parasitization }=\frac{\sum \text { arisen parasitoid imago }}{\sum \cdot \text { chinensis imago }+\sum \text { arisen parasitoid imago }} \\
& \times 100 \%
\end{aligned}
$$

Data analysis. Data analysis used in this research is variance (Anova) If showeding the real effect then tested using test of real difference Honest (HSD) at 5\% level.

Table 1. Type of Liriomyza On the Palu Valley of Palu in Langaleso Village, West Dolo Sub

\begin{tabular}{|c|c|c|}
\hline No & $\begin{array}{l}\text { Picture from } \\
\text { Internet }\end{array}$ & $\begin{array}{c}\text { Picture from } \\
\text { Identification } \\
\text { Result }\end{array}$ \\
\hline
\end{tabular}
District.

1

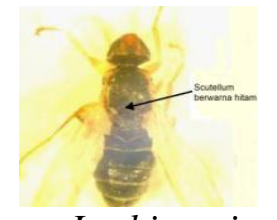

L. chinensis

(Shahabuddin et al., 2012)

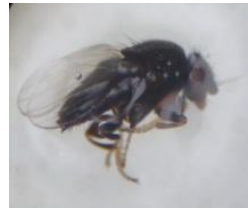

L. chinensis

(putu, 2016)

- Its imago was black and on the back (scutellum) imago was also black with length of $2.06 \mathrm{~mm}$.

- Agromyzidae: on the wings, the costa was broken out at the end of Sc (near R1, if Sc was less obviously integrated with R1) the first M2 cells were usually present but the M3 transversed veins sometimes close to the wing base. Abdomen is often depressed, and female ovipositor is often long (Shiao, 2004).

- $\quad$ : L. Chinensis Species can be distinguished from other species especially on the back of black (scutellum), whereas in L. huidobrensis and L.sativae at the end of the back there is a yellow color. (Spencer, 1989; Shiao, 2004). 
Table 2. The average number of L. chinencis bend of age $3.4,5,6,7,8$ (MST) on the treated onion and without treatment (control).

\begin{tabular}{|c|c|c|c|c|c|c|c|}
\hline \multirow{2}{*}{ Treatment } & \multicolumn{6}{|c|}{ Week - } & \multirow{2}{*}{$\begin{array}{c}\text { Total } \\
\text { average }\end{array}$} \\
\hline & 3 & 4 & 5 & 6 & 7 & 8 & \\
\hline PT0 & 4.33 & 3.00 & 1.67 & 1.00 & $0.33 a$ & 0.00 & 1.72 \\
\hline PT2 & 1.33 & 1.67 & 1.33 & 1.00 & $0.33 a$ & 0.33 & 0.98 \\
\hline PT4 & 3.33 & 2.33 & 1.33 & 2.00 & $1.00 \mathrm{~b}$ & 0.67 & 1.77 \\
\hline PT6 & 1.00 & 2.00 & 1.00 & 0.33 & $1.00 \mathrm{~b}$ & 0.33 & 0.94 \\
\hline Control & 1.33 & 3.00 & 3.00 & 2.33 & $4.33 c$ & 4.67 & 3.11 \\
\hline
\end{tabular}

Description : The numbers that followed by the same letter in the same column did not differ on the 5\% HSD test level

Table 3. Types of Parasitoid Pests L. chinensis and Its abundance in shallot crops given tomato trap (treatment) and onion plants red without tomato trap (control).

\begin{tabular}{lcc}
\hline Species & $\begin{array}{l}\text { The number of } \\
\text { Parasitoid given } \\
\text { trap(treatment) }\end{array}$ & $\begin{array}{l}\text { The number of } \\
\text { Parasitoid } \\
\text { without trap } \\
\text { (control) }\end{array}$ \\
\hline $\begin{array}{l}\text { H.varicorn } \\
\text { is }\end{array}$ & 7 & 9 \\
Opius sp. & 5 & 4 \\
\hline
\end{tabular}

Table 4. Parasitzation parasitoid level of Liriomyza chinensis on shallot plant with control and treatment.

\begin{tabular}{cccc}
\hline Treatment & $\begin{array}{c}\text { The } \\
\text { number of } \\
\text { parasitoids }\end{array}$ & $\begin{array}{c}\text { The } \\
\text { number of } \\
\text { L.ninencis }\end{array}$ & $\begin{array}{c}\text { parasitioid } \\
\text { parasitization } \\
\text { level }(\%)\end{array}$ \\
\hline T0 & 3 & 10 & 23.07 \\
T2 & 3 & 8 & 27.27 \\
T4 & 5 & 14 & 26.31 \\
T6 & 4 & 11 & 26.66 \\
K0 & 10 & 41 & 19.60 \\
\hline
\end{tabular}

\section{RESULTS AND DISCUSSION}

The number of Liriomyza and $L$. Chinencisbends. Hasil identifikasi spesimen di laboratorium menunjukan bahwa, spesies Liriomyza sp. yang menyerang tanaman bawang merah Lembah palu yaitu L. Chinensis Based on HSD test results 5\% showed that the treatment of planting with tomato trap plants with different planting time had significant effect on the number of bends on the observation.

Types and Abudnance of Parasitoid. Based on observation, maintenance, and identificationand no significantly affect on observations 3, 5, 6, and 8 (MST). the average number of L. chinencis bends can be seen in the table below and 7 (MST), and did not significant.

Parasitoid Parasitization Level. Based on observation and maintenance of Liriomyzachinencis and parasitoid it can be known parasitoid parasitization level presented in the table below.

\section{Discussion}

The identification results showed that Liriomyza species that attack on shallot cultivation land in Sub district Langaleso Dolo Village was L. chinensis (Table 1). The main morphological character that distinguished L. chinensis from other Liriomyza was scutellum in black $\mathrm{L}$. chinensis. The results of Shahabuddin et al. (2012), indicated that L. chinensis has a dark gray or near-black mesoscutellum and a simpler abdominal color pattern whereas in other Liriomyza it has a more complex abdominal color pattern and a yellow mesoscutellum. Another characteristic of L. chinensis morphology is its shiny yellow (coxae and femur) limbs (Spencer, 1989; Shiao, 2004). 
Field observationshoweded that L. chinensis initial attack was white spots caused by a pseudo female pink ovipositor prick. L chinensis started to occur when plants were 5 to 10 HST (Day after Planting). HSD 5\% test result at plant age of $3,4,5,6,7$, and 8 MST (Table 2) showeded that the average number of L.chinencister high was found in control plants aged $8 \mathrm{MST}$ with average number (4 , 67) was very different from the plants planted in conjunction with the trap plant (T0) or the plants treated with age 8 MST with the average number of (0.33). When viewed from that value, the plants trapped did not attack L. Chinencis. Haliments indicated that the apper trap can reduce the number ofL.chinencis bends. Therefore the use of tomato as trap plant was effective to control the pest.

L. chinensis was one of the pests that snored red onion leaf. Early symptoms of the attack in the form of white spots on the leaves due to puncture ovipositor imago females when laying egg.Larva just come out directly into the leaf cavity and then snore the leaves from the inside, namely the leaf mesophyl. Bend direction usually from the top down to the tuber. Damage seen on the red onion cropcauses rotting tubers and leaves to wilt dry brownish-white color like burnt (Nonci and Muis, 2011). Silano (2009) suggested that the initial attack of leafminer on the onion plant occurs in 2-3 weeks after planting (mst). Early symptoms in the stricken form of white spots due to pussycoditor imago female when laying the egg. The attack on the plant occurs from the beginning of growth (1-10 hst) and continues until the tuber maturation phase (51-65 hst).

Symptoms of the attack in the form of a curved corona larva. On heavy attack, almost all the leaf blades filled by the bend so that the leaves become dry and white brownish like burnt, in addition to attacking the leaves, larvae leaf nutmeg leaf on red onion plants can enter the tubers and cause the garlic bulb becomes rotten and this is what distinguishes it with other types of leafminer fly.

Supartha et al., (2002) stated that intrinsic factors and extrinsic factors also influence the development of insects, intrinsic factors such as $L$. chinencis resistance while extrinsic factors such as environmental factors that include the existence and adequacy of food, climate, space, competition and enemies natural. The environment plays an important role in population development and insect growth, especially for food and reproduction, the presence and abundance of host plants is a factor that supports the development of $\mathrm{L}$. chinencis and parasitoid population.

Mizu (2007) stated that the intercropping system often cause a decrease in pest population density than monoculture system. This was because the role of volatile chemical compounds (atsiri) removed and visual disturbance by non-host plants would affect the behavior and speed of insect colonization in plants host. For example, garlic plants grow between cabbage plants that can decrease the population of Plutella xylostella that attacks the cabbage plant. This is because the compound released by garlic is not the same as the compound released by cabbage plants so that P. xylostella does not like the habitat of the intercropping plants. The trapping plants do not necessarily belong to different species, because the trap plants can be from the same species but the plants are more attractive to pests compared to other plants or in other words the plant is preferred by pests as a place to eat and lay eggs compared to other plants.

The results of identification in the laboratory showed that, there was a parasitoid two species found in association with L. chinensis, ie $H$. varicornis (familiEulopidae) andOpius sp. (Family Braconidae). (Table 3 and 4). Of the two parasitoids, the parasitoid $\mathrm{H}$. varicornis was the most dominating parasitoid in the field when compared to the parasitoid Opius sp. The abundance of Hemiptarsenus varicornis in the field and the extent of their host range indicated that the parasitoid had a high 
potential as a natural enemy to control leafminer pests. This parasitoid has been reported to be an effective natural enemy to control leaf clippers in a variety of host plants (Rauf et al., 2000, inPurnomo 2003).

Some of the parasitoids reported associated with Liriomyza include H. varicornis, Opiuschromatomyiae, Asecodesdeluchii, Neochrysocharisformosa, Gronotoma Micromorpha (Rauf et al., 2000; Purnomo, 2003).

When viewed from the Table above the highest parasitoid parasitization level of L. chinencis was found in plants given tap trap (T2) with parasitization level of 27.27 while the lowest parasitization level is in control plants with parasitization level of 19.60. This indicated that the tomato plants that were used as plant traps are quite effective in controlling pest attacks. Supartaet al., (2003) stated that the high degree of parasitoid parasitization to Liriomyza is due to the level of preference, compatibility and availability of the parasitoid host. If the parasitoid host is large and the environment is very supportive it greatly affects the parasitoid parasitization level of the host.

High parasitoid diversity also affected the level of parasitizationon insecthost, the more host the more atacked host by the parasit and vice versa. The high abundance of natural enemies in the field can increase the mortality of thehost, and the way of naturally cultivating plants without the use of chemicals, thus increasing the effectiveness of natural enemies. Therefore a more eco-friendly control technique was required. One way to do this was to inventory the varieties of plants that showed the characteristics of resistance to pest attacks. Naturally plants have several defense mechanisms to fight against herbivore insect attacks either with physical, chemical or combined resistance (Mellodan Silva Filho, 2002).

\section{CONCLUSION AND SUGGESTION}

\section{Conclusion}

Cultivation of onions with tomato traps had higher L. chinencis pests (average number of corals by 4.67per clumps) and very different from red onions that used tomato traps (average number of bend by 0.33 per hill).

There were two species of parasitoid found in shallot plants in Langaleso village, Dolodan subdistrict, in association with Liriomyza pest. Varicornis (family Eulopidae,) and Parasitoid Opius sp. (Braconidae family).

At the parasitic level of $\mathrm{L}$. chinencis parasitoid pest, the onion plant that was given tomato trap plant had a parasitization rate of $23 \%$ to $27 \%$ and at the parasitization level in plants without tomato traps of $19.60 \%$.

\section{Suggestion}

It is suggested to do further research on the types of Liriomyza chinencis parasitoids, other hosted plant by using different trap plants.

\section{REFERENCES}

Agus N., 2007. Konservasi parasitoid hemiptarsenus varicornis grinault sebagai agens pengendali hayati hamaliriomyza huidobrensis blanchard di pertanaman kentang.Prosiding Seminar Ilmiah dan Pertemuan Tahunan PEI dan PFI XVIII Komda Sul-Sel, 2007. Fakultas Pertanian Universitas Hasanuddin.

Balai Perlindungan Pertanian, Perkebunan dan Peternakan Sulawesi Tengah (BP4). 2006.Laporan Tahunan tentang hama tumbuhan. BP4 Sulteng.

Fisher N, Ubaidillah R, Reina P, dan La Salle J.2006. Liriomyza Parasitoids of South East Asia.Australia.http://www.ces.csiro.au/science/Liriomyza_ver3/key/Liriomyza_Parasitoids _Key/Media/Html/identify.html.tgl.[7 September 2006]. 
Kabaru dan Gichia, 2001. Insecticidal Activity Of Extracts Derived From Different Parts Of The Mangrove Tree Rhizophora mucronata Lam. (Rhizophoracea) Againts Three Arthropods. Afr J Sci technol 2:44-49.

Konishi K. 1998. An illustrated key to the hymenopterous parasitoids of LiriomyzatrifoliiinJapan.http://cse.naro.affrc.go.jp/konishi/e-key1.html.[8 November 2015]

Nonci, N. dan A. Muis, 2011. Efektivitas Beberapa Teknik Pengendalian Terhadap Lalat Pengorok Daun Liriomyza chinensis Kato (Diptera: Agromyzidae) pada Bawang Palu. Laporan Hasil Penelitian dan Pengkajian. Balai Pengkajian Teknologi Pertanian SulawesiTengah, Palu. 64hlm.

Mello MO dan Silva-Filho MC. 2002. Plant-insect interactions: An evolutionary arms race between two distinct defense mechanisms. Braz. J. PlantPhysiology 14(2):71-81.

Mizu.2007. Pemanfaatan tanaman perangkap dan Minyak/Senyawa Atsiri Dalam Pengendalian Populasi HamaTanaman,(Online) http://horticlinic.blogspot.com

Purnomo, Rauf A, Sosromarsono S, dan Santoso T. 2003. Parasitisme Hemiptarsenus varicornis (Girault) (Hymenoptera: Eulophidae) terhadap lalat pengorok Daun Liriomyza Huidobrensis (Blanchard) (Diptera: Agromyzidae) pada tanaman kacang Endul (Phaseolus vulgaris L.) di Ciloto, Jawa Barat. J. HPT Tropika 3 (1): 13-16.

Rauf, A; B. M., Shepard dan M.W. Johnson. 2000. Leafminers in vegetables, ornamentalplants and weeds in Indonesia: Surveys of Host Crops, Species Composition and Parasitoids. Int. J. Pest. Manag 46: 257-266.

Rustam, R., A. Rauf., N. Maryana., Pujianto dan Dadang. 2008. Komunitas Parasitoid lalat pengorok daun pada tanaman sayuran dataran tinggi. J. Natur Indonesia 11 (1): 40-47.

Saleh SM, Samsuddin dan Maemunah. 2009.Karakterisasi bawang merah lokal Palu.Prosiding SeminarNasional dan Workshop Inovasi TeknologiPertanian yang Berkelanjutan MendukungPengembangan Agribisnis dan Argoindustridi Pedesaan. Balai Besar Pengkajian danPengembangan Teknologi Pertanian.Palu 10-11November 2009.

Shahabuddin, A. Anshary, Gellang, A. 2012. Tingkat Serangan \& Jenis Lalat Pengorok DaunPada Tiga Varietas Lokal Bawang Merah di Lembah Palu, Sulawesi Tengah. Prodi Agroteknologi, Fakultas Pertanian. Universitas Tadulako.

Shiao SF. 2004. Morphological diagnosis of six Liriomyza spesies (Diptera: Agromycidae) of quarantine importance in Taiwan. Appl. Entomol. Zool. 39:27-39

Shelton A.M and Badenes-Perez F.K., 2006.Concept and Aplications of Trap Cropping in pest Management. Departemen of Entomology, Cornell University New York State Agricultural experiment station.

Spencer, K.A. 1989. Leaf miners.InP.P. Kahn (Ed.). Plant Protection An Quarantine, Vol. 2. Selected Pests and Pathogens of Quaranti Significan CRCPress, Boca Raton, Florida.p .77-98.

Setyono, A.B. 2009. Waspadalah terhadap hamagandrong.www.naturalnusantara.co.id. [6 September 2009].

Susilawati. 2004. Lalat pengorok daun Liriomyza sativae Blanchard hama baru pada beberapa sayuran dataran rendah. J. Hort.14 (4): 279-286. 
Supartha, I. W. 2002. Pengembangan hayati Liriomyza.spp. pada berbagai tanaman sayuran di Bali. Makalah Utama Seminar Pengembangan Pengendalian Hayati Pada Tanaman Sayuran di Bali. 14 Januari 2002.BPTPH Denpasar. Hal.11

Supartha, I. W., Bagus, I G. N. DanSudiarta,P. 2003. Kelimpahan populasiLiriomyzaspp. (Diptera:Agromyzidae) dan Parasitoid pada tanaman sayurandataran tinggi.Agritrop, 24 (2) : $43-51$ 